https://doi.org/10.31470/2706-7904-2021-16-147-150

\title{
ТАКСОНОМІЯ АСОЦІАЦЙ ПРОВІДНИХ КОНЦЕПТІВ РЕЛІГІЙНОГО ДИСКУРСУ
}

Associations of Leading Concepts of Religious Discourse: Cluster Analysis

\author{
Natalia Kostruba \\ Ph.D. in Psychology, Associate Professor \\ Lesya Ukrainka Volyn National University (Ukraine) \\ nataliia.kostruba@vnu.edu.ua \\ https://orcid.org/0000-0002-3852-4729
}

\begin{abstract}
The abstract reveal the problem of the prevailing ideas of young people about the leading religious concepts. The aim of the research is to analyze students'verbal representations of religious discourse concepts. To define the leading concepts, we used a structural approach, which the classic components are: behavioral (prayer, sermon, sacraments), emotional-motivational (faith, sin) and cognitive (religion, church, priest). We used free WAT (word association test) for psycholinguistic analysis. The results of the cluster analysis showed that in the minds of young people religious discourse is represented through two main semantic categories, namely faith and the church - the priest.
\end{abstract}

Key words: association, religious discourse, concept, cluster analysis.

\section{Вступ Introduction}

Дослідження релігійного дискурсу та його концептів є об'єктом вивчення багатьох суміжних галузей знань (психології, філології, соціології, теології тощо). Актуалізація психологічних досліджень у цьому напрямку пов’язана із поширенням інтернету та мас-медіа у всіх сферах життя, і у релігійній також. Релігія хоч і здається традиційною і непорушною системою, проте вона змінюється для того, щоб утримати та залучити представників молодого покоління. Розширення сфери функціонування релігійного дискурсу є причиною трансформації бачення та розуміння основних його концептів. Про аксіологічну реконструкцію релігійної концептосфери сучасної особистості стверджує багато наукових праць (Крисальна, 2013; Singh \& Thuraisingam, 2011). Використання церквою сучасних методів комунікації спричинює появу нових смислів та інтерпретацій у релігійній сфері. Існують дослідження, які акцентують увагу на лінгвістичних особливостях і ролі мови у підтримці релігії. Так, 
науковці P.K.H. Singh та T. Thuraisingam обгрунтовують роль мови у формуванні систем релігійних значень, а також стверджують, що релігійні мова має змінюватись відповідно до викликів часу (Singh \& Thuraisingam, 2011). Саме тому, метою дослідження $\epsilon$ аналіз вербальних репрезентацій концептів релігійного дискурсу представниками молодого покоління.

Кожен тип дискурсу визначається серед інших своїми базовими концептами. Науковці у межах своїх досліджень роблять акцент на різних концептах, наприклад «Бог» (Мацьків, 2006), «віра» (Парахневич, 2012) тощо. Для виокремлення провідних концептів релігійного дискурсу ми застосували структурний підхід, одним із основоположників у психології є Л.С. Виготський (Выготский, 1982), у межах якого класичними є компоненти: поведінковий, емоційно-мотиваційний i когнітивний (Табл. 1).

\section{Таблиця 1}

Провідні концепти релігійного дискурсу

\begin{tabular}{lll}
\hline \multicolumn{3}{c}{ Релігійний дискурс } \\
\hline \multicolumn{3}{c}{ Компоненти } \\
\hline Когнітивний & Емоційно-мотиваційний & Поведінковий \\
\hline Релігія & \multicolumn{1}{c}{ Концепти } \\
Церква & Віра & Таїнства \\
Священик & Гріх & Молитва \\
\hline
\end{tabular}

Так, у когнітивному компоненті вважаємо найбільш значущими концепти «релігія», «церква», «священик», це провідні елементи створених людиною релігійних організацій та інституцій. Емоційно-мотиваційний компонент релігійного дискурсу відображає провідні концепти «віра» та «гріх», оскільки будь які релігійні почуття і переживання грунтуються на вірі в Бога, богів чи сили природи, а також на визнанні гріховності людини. Поведінковий компонент відображає най поширеніші способи практик та сповідування релігії, а саме «молитва», «проповідь», «таїнства».

\section{Методи та методики дослідження Methods and Techniques of the Research}

Для реалізації мети нашого дослідження було використано вільний асоціативний експеримент. Загалом, це метод «виявлення зв’язків уявлень, які зумовлені попереднім досвідом і завдяки яким одне уявлення, що з'являється у свідомості, викликає на основі схожості, суміжності або протилежності (Сурмач, 2012: 22). Асоціативний експеримент, як метод дослідження семантичного простору студентства активно використовують сучасні науковці (Загородня, 2018; El-Dakhs, 2017). 
Вибірку склали 246 студентів віком 17-20 років із Волинського національного університету імені Лесі Українки.

\section{Результати}

Results

Детальні результати аналізу асоціативних реакцій студентів описано у попередніх публікаціях автора (наприклад див. Коструба, 2019). Загалом, молодь схильна використовувати метафоричні засоби мови, щоб підкреслити містичність i відсутність конкретної визначеності концептів віра, релігія, таїнства, молитва, гріх. Проте, такі концепти як церква, проповідь, священник у свідомості студентів $\epsilon$ розглядаються зазвичай у вузькому значенні через призму периферійних значень i зовнішніх ознак.

Кластерний аналіз методом Варда показав, що у свідомості молоді концепти релігійного дискурсу репрезентується двома семантичними групами асоціацій: (1) «віра» i (2) «церква - священник». Другий кластер представлений декількома підкластерами: (1) «релігія - гріх», найбільш близькими асоціаціями до яких $\epsilon$ «проповідь» і «таїнства»; (2) «молитва - релігія» 3 найближчою асоціацією «гріх»; (3) «священник - релігія» 3 найближчою асоціацією «молитва» (Рис. 1).

\section{Рис. 1}

Таксономія асоціацій провідних концептів релігійного дискурсу

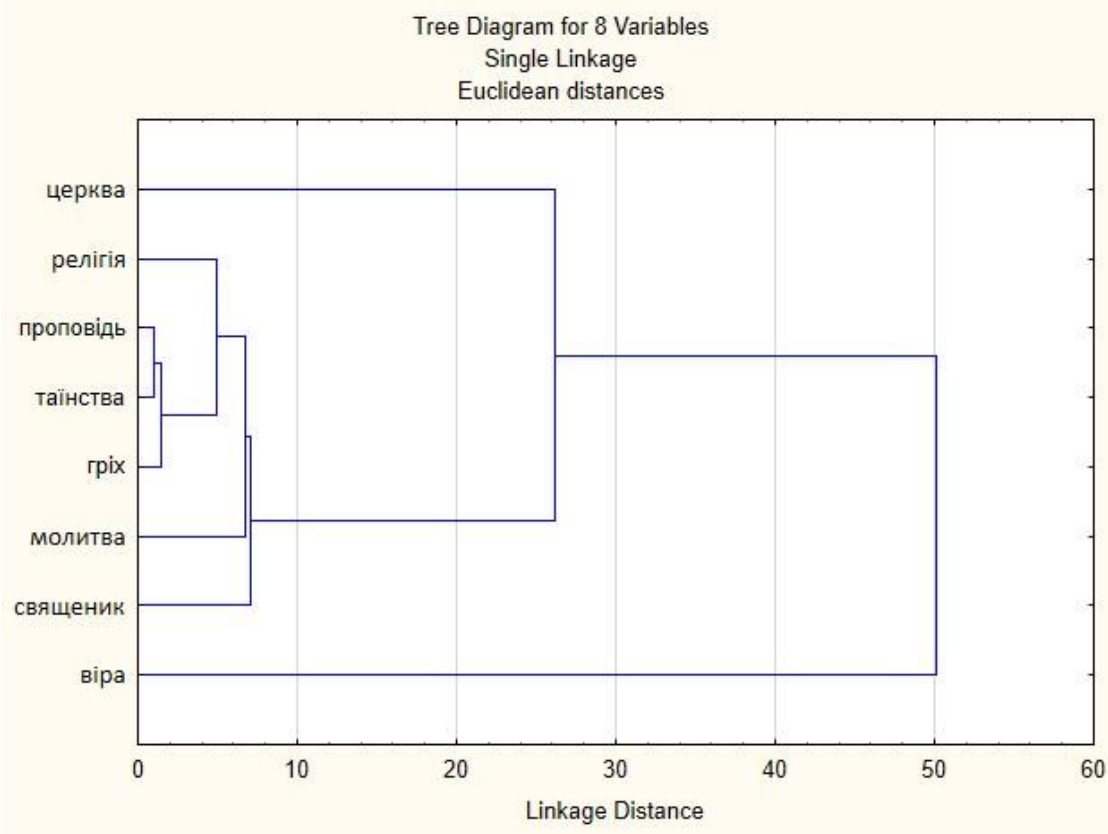




\section{Висновки \\ Conclusions}

Здійснений емпіричний аналіз панівних уявлень молоді щодо провідних релігійних концептів дає можливість стверджувати, що опитаним студентам складно визначати поняття зазначеного дискурсу. Про цей факт свідчить частота використання метафоричних та периферійних реакцій. Результати кластерного аналізу продемонстрували, що у свідомості молоді релігійний дискурс репрезентується через дві основні семантичні категорії, а саме віра та церква священник. Таким чином, студенти виокремлюють дві складові релігії та релігійності особистості. Одна сфера стосується вірувань особистості, інша обрядових традицій та функціонування релігійного культу.

\section{Література References}

Выготский, Л.С. (1982). Проблема развития в структурной психологии. Собр. соч. (Т. 1-2). (Т. 1). Москва.

Загородня, О.Ф. (2018). Асоціативні поля суспільно-політичної лексики в мовній картині українців (комп'ютерне опрацювання результатів психолінгвістичного експерименту). Дис. канд. філол. наук. Житомир: Житомирський державний університет імені Івана Франка.

Коструба, Н. (2019). Концепт «молитва» у свідомості молоді: психолінгвістичний аналіз. Психологічні перспективи, 34, 65-79. https://doi.org/10.29038/2227-1376-2019-34-65-79

Крисальна Ю.В. (2013). Релігійні концепти в нерелігійній комунікації (на матеріалі сучасних англомовних медійних текстів). Мовні і концептуальні картини світу, 46(2), 248-256.

Мацьків, П.В. (2006). Кониептосфера БОГ в украйнському мовному просторі. Дрогобич: Коло.

Парахневич, Е.В. (2012). Концепт «Вера» в текстовом пространстве журнала «Путь» (19251940). Вестник Волгоградского государственного университета. Серия 2: Языкознание, 2, 162-166.

Сурмач, О.Я. (2012). Асоціативний експеримент та вербальні асоціації у психолінгвістичних дослідженнях. Наукові записки Наиіонального університету «Острозька академія». Серія Філологічна, 29, 22-24.

El-Dakhs, D. (2017). The Effect of Language Exposure and Word Characteristics on the Arab EFL Learners' Word Associations. Journal of Psycholinguistic Research, 46(4), 1033-1052. https://doi.org/10.1007/s10936-017-9477-z

Singh, P.K.H., \& Thuraisingam, T. (2011). Language for reconciliation in religious discourse: A critical discourse analysis of contradictions in sermons explored through the activity theory framework. Multilingua-journal of cross-cultural and interlanguage communication, 30(34), 391-404. https://doi.org/10.1515/mult.2011.019 